\title{
Epidemiological and clinico-pathological findings of HAM/TSP from Chile and Japan
}

Luis Cartier Rovirosa ${ }^{1}$

\section{RESUMEN}

En Japón el HAM/TSP está particularmente ligado a la seroprevalencia del virus; Kyushu tiene una seroprevalencia para HTLV-I del 8\% y cuenta con el $71.5 \%$ de los HAM/TSP de todo el Japón. En Chile la seroprevalencia para HTLV-I es del $1 \%$ en todo el país y la prevalencia del HAM/TSP se relaciona más bien con la densidad poblacional; el $45 \%$ de los pacientes son nacidos en Santiago. Tanto en Chile como en Japón sólo el 80\% de los pacientes con paraparesia espástica progresiva se asocian con HTLV-I. En definitiva, la prevalencia del HAM/ TSP en Chile es de 2 por 10.000 habitantes y de 0,68 100.000 en Japón.

Sin embargo, la expresión clínica de la enfermedad es idéntica en Japón y Chile, con una edad de comienzo de 43,8 años en Japón y 46,6 años en Chile. En ambos grupos hay un claro predominio del sexo femenino 2,2 y 2,9 a 1 en Japón y Chile, respectivamente. El trastorno de la marcha es la forma más frecuente de comienzo que se manifiesta en el 65 al $70 \%$ de los pacientes, así como los trastornos de la micción (vejiga neurogénica) entre 20 y $33 \%$ de los casos. La evolución clínica de la paraparesia también resulta semejante tanto en la forma de progresión, como en el tiempo de llegar a la paraplejia. Los cambios en los exámenes de laboratorio tales como aumento de $\mathrm{IgG}$, pleocitosis en el líquido encefalorraquideo en el $35 \%$ de los casos. Atrofia de la médula espinal y los cambios de señal en la substancia blanca subcortical en la RNM; así como las alteraciones en los potenciales evocados en el $75 \%$ de los casos. Difieren en que los casos japoneses muestren trastornos periféricos en la EMG que no tienen los pacientes chilenos.

Desde el punto de vista neuropatológico las lesiones de la médula espinal y encefálicas son idén-

1 Professor of Neurology. Department of

Neurological Science. Medicine Faculty,

Universidad of Chile. ticas. La diferencia entre investigadores chilenos y japoneses reside en la interpretación patogénica.

Las enfermedades asociadas a HTLV-I como el Síndrome de Sjügren es mucho más frecuente entre los pacientes chilenos $(40 \%)$ que entre los japoneses que sólo llega al $25 \%$. Asimismo las lesiones cutáneas paralinfomatosas, se observan en el $25 \%$ de los HAM/TSP en Chile, no siendo tan frecuentemente observadas en Japón. Los linfomas asociados a HAM/ TSP, que es muy alta, superan el 10\% en Chile, siendo excepcionales en Japón.

Por otra parte, artropatías y broncoalveolitis son mucho más frecuentes en Japón así como la ubeitis que no ha sido descrita en Chile.

En conclusión, el HAM/TSP es similar en Chile y Japón, difiriendo en aspectos epidemiológicos y de patologías asociadas, donde factores genéticos o ambientales seguramente juegan algún rol.

\section{Introduction}

In 1985, it was reported that the limphotropic virus type I (HTLV-1) was associated with the tropical spastic paraparesis (Gessain 1985). Osame et al. in 1986 established this association in Japan (Osame 1986), and Cartier et al. in 1989 in Chile (Cartier 1987). The HTLV-1 associated myelopathy (HAM) and tropical spastic paraparesis associated with HTLV-I (TSP) are the same entity (HAM/TSP).

The HAM/TSP is strongly linked to seroprevalence of HTLV-I in Japan. Kyushu has a seroprevalence of $8 \%$ and has $71.5 \%$ of the HAM/ TSP of all Japan (Takesaki 1996, Osame 1990). In Chile the HAM/TSP is related with the numbers of inhabitans. Santiago, the most populated area of Chile, has HTLV-I seroprevalence nearly to $0.75 \%$ and has $52 \%$ of the HAM/TSP patients (Cartier 1996). The highest seroprevalence in Chile is $7.5 \%$ found in Atacameños in the northern part of Chile (Cartier 1993).

The progressive spastic paraparesis is associated with HTLV-1 in about $82 \%$ of the cases in Japan, 
(Takesai 1996; Osame 1990) and in Chile only 63\% are seropositives to HTLV-I. But some seronegatives Progressive Spastic Paraparesis are also associated with HTLV1, because they have positive tax gen of provirus HTLV-I by PCR. This special group is a $50 \%$ of seronegatives patients, and it represents $20 \%$ of the total HAM/TSP. (Ramírez 1998). These findings suggest that in Chile, like in Japan, there are a similar paraparesia-virus relation.

The subtype of HTLV-I found in Chile belongs to the Cosmopolitan group and the transcontinental sub-group. This is the same HTLV-I sub-group of Ainu people, the oldest inhabitants of Japan and it is phylogenetically very close to the Chilean virus. This was related to Araucan HTLV-I, and the ancient population virus in Japan could be significant, although the molecular evolution rate of HTLV-I was unknown (Miura 1997).

In Chile the HAM/TSP has been found in all the country. Only in the Salvador Hospital we have studied about 260 cases of Progressive Spastic Paraparesis patients, that were born in various places of Chile. It has been estimated that HAM/ TSP prevalence in Chile is 2:1.100.000 inhabitants; the possibility of illness is 5:11.000 HTLV-I carriers (Cartier 1996). The prevalence of HAM/TSP in Japan is $0.68: 100.000$ inhabitans and the possibility of illness for HTLV-I carriers is about 2,3:1.000. In Japan most cases come from Kyushu and Okinawa, the same area where ATLL is more prevalent than HAM/TSP. In Chile ATLL is ten time less prevalent than HAM/TSP (Cartier 1986, Takesaki 1996).

This epidemiological difference between Chile and Japan may be interpreted by a distinct genetic background or different environement. There are evidences that genetic factors expressed by HLA haplotipes play a rol in the incidence of HAM/TSP or ATLL. The study of cellular immune response to HTLV-I by analyzing HLA haplotype shows a specific group that has a high immune response (HAM/TSP), and other group that has a low immune response to HTLV-I (ATLL). The HLA haplotypes associated with HAM/TSP are: in class I (ABC) A24CW7B7, Al 1 CW 1 BW54, etc.; in class II (BRB 1, DqB 1) 0101-0531-0803-0401-0405 etc. (Sonoda 1992).

The clinical presentation of HAM/TSP is similar in Japan and Chile. The average age of onset in Japan is 43, 8+ 17,4 (Nakagawa 1995, Osame 1987), in Chile is 46,6+ 14,2 (Cartier 1996); There are no descriptions of infantile HAM/TSP (under 15 years) in Chile. Probably this differences arise from a non systematic research of HTLV-I between children paraparesis. The female predominance is found in both countries. The male: female ratio is 1:2,2 in Japan and 1:2,9 in Chile (Cartier 1996, Nakagawa 1995).

The initial symptom in most cases is a gate disturbance. This form of onset is present in $65 \%$ of Japanese cases and $70 \%$ of Chilean cases. The onset of HAM/TSP is usually slow. The examination revealed a bilateral pyramidal syndrome, with spasticity, and hyperreflexia in the lower limbs, Babinski sing. The muscular weakness is predominant in gluteus, knee flexors and foot dorsiflexors muscles. This clinic compromise is related with the distal lesion of the pyramidal tract. The urinary disturbance is also frequent in the beginnings of HAM/TSP, in $33 \%$ of the Japanese patient and $20 \%$ of the Chilean patients. The onset with sensitive symptoms like numbness, burning sensation or coldness of the legs is $13 \%$ and $20 \%$ in the Japanese and Chilean patients respectively (Nakagawa 1995, Cartier 1992).

Constipation is a form of onset in $6 \%$ of HAM/ TSP in Japan; in Chile this symptom is not clearly expressed, but there are some cases with fecal incontinence. Lumbago, is a very common symptom in the onset, it is $9 \%$ between Japanese patients and $15 \%$ in the Chilean patients. Hand tremor has been present in $3 \%$ of the Japanese patients, and pseudobulbar paresis in $2 \%$ of the Chilean patients (Cartier 1996, Nakagawa 1995).

The disability gate is a particular variable for escha patient, also the interval between the onset of disease and the definitive inability to walk. In Japan the paraplegia can be as rapid as seven days or slow, with a progression of 35 years. In Chile the most wild case has 32 years of evolution and moreover she could a have walked. The most rapid case was a transfused patient who got paraplegic in two months (Nakagawa 1995, Cartier 1995).

The laboratory findings are similar. In the blood count there are no significant increase of $\mathrm{T}$ lymphocytes CD3 or CD4; the lobulated lymphocytes (leukemoides) are present in many cases (35). Increase of gammaglobulines, especially $\operatorname{IgG}$ over 1800 , is shown in a significant number of cases between Chilean and Japanese patients. In the cerebral spinal fluid the HTLV-I is positive in most cases; there are cytosis over 6 or 7 cells in $1 / 3$ of the 


\begin{tabular}{|c|c|c|}
\hline OSAME et al & \multicolumn{2}{|c|}{ CARTIER et al } \\
\hline $\begin{array}{l}0 \text { Normal gait and running } \\
1 \text { Normal gait but runs slowly }\end{array}$ & 1 Normal gait & (pyramidal syndrome) \\
\hline $\begin{array}{l}2 \text { Abnormal gait (Staggerings or Spastic) } \\
3 \text { Abnormal gait and unable to run }\end{array}$ & $\begin{array}{l}2 \text { Paretic spastic gait } \\
\text { Without support }\end{array}$ & a) Very efficient \\
\hline $\begin{array}{l}4 \text { Needs support while using stairs but walks } \\
\text { without assistance }\end{array}$ & & b) Less efficient \\
\hline 5 Needs one hand support in walking & $\begin{array}{l}3 \text { Paretic spastic gait } \\
\text { Needs support }\end{array}$ & a) Efficient \\
\hline 6 Needs two hands support in walking & & b) Inefficient \\
\hline $\begin{array}{l}7 \text { Unable to walk but can crawe with hands } \\
\text { and knees }\end{array}$ & 4 Without gait & (can stand up) \\
\hline $\begin{array}{l}8 \text { Unable to crawe but can turn sideways in bed } \\
9 \text { Unable to turn sideways but can move the toes } \\
10 \text { Completely bedridden }\end{array}$ & 5 Bedridden & $\begin{array}{l}\text { a) Can turn sideways in bed } \\
\text { b) Completely bedridden }\end{array}$ \\
\hline
\end{tabular}

cases. Also, there are oligoclonal bands and raise of IgG index in 2/3 of the cases. (Nakagawa 1995, Cartier 1992) The Japanese studies of neopterin have shown that is related with the intensity of inflammatory changes in CSF (Nakagawa 1995). Also there are expressions of matrix metalloproteinases (MMP-2 and MMP-9) in CFS.

MMP-9 is a pathological finding in HAM/ TSP, and could be a very good marker for the identification of this paraparesis (Umehara 1998, Giraudon 1996).

The radiological study shows an atrophy of spinal cord in more than $60 \%$ of the cases, specially in patients with an evolution over ten years. Associated with these findings, in $2 / 3$ of the cases, with MNR is possible in the subcortical white matter to see patchy of hyperintensity areas in T2 sequence (Kira 1991, Cartier 1997, Ferraz 1997).

In most HAM/TSP from Japan and Chile patients reported very similar electrophisiological findings. There are delayed or absent cortical potentials in the central conduction time of somatosensory evoked potentials (SSEPs) (Arimura 1987, Kakigi 1998, Castillo 1991). These findings suggest the presence of a lesion of the posterior tracts of the spinal cord below the cortical level. The visual evoked potential and brainstem auditory evoked potentials are generally normal in Chilean and Japanese patients. The motor evoked potentials (MEPs) show absent or prolonged MEPs, but there are no correlations with the severity of the symptoms (Tomita 1989). These findings are in keeping with the neuropathological lesions, which affect the longest axons of the pyramidal and Goll's tracts (Cartier 1997). Electromyography studies in the Chilean patients do not show abnormalities in the peripheral nerve conduction, including F-wave and H-reflex (Castillo 1995).

However, the Japanese patients present electromyografic changes nearly to $50 \%$ of the studied cases, different from the Chilean patients in this aspect (Arimura 1987).

The neuropathological findings are identical in Chilean and Japanese cases. The macroscopic appearance of the spinal cords shows thinning in the thoracic region in $66 \%$ of the cases. The brain and brainstem look normal in the majority of cases (Cartier 1997, Iwasaki 1990, Kobayashi 1991).

The histology shows the pia-arachnoid with patchy thickening and in some cases lymphocytic cuffing in the meningeal vessels. In the lateral columns there is loss of myelin and axons in all cases; the severity of axonal loss is related to the atrophy of the spinal cord. In $2 / 3$ of cases the axomyelinic degeneration of the pyramidal tracts is prominent in the dorsal and lumbar segments with little involvement of the cervical areas; in $1 / 3$ the severity of the changes is similar from the lumbar 
to the cervical segments. Frequently, it is observed involvement of the anterior pyramidal tracts. In most cases, the myelin of the posterior columns is pale in the cervical segments in the Goll's bundles, this pallor strangely arrives to the dorsal segments (Cartier 1997, Izumo 1989, Iwasaki 1990).

Using the Bodian's stain, thick or degenerated axon spheroids are seen. In an ultrastructural study some axons are filled with masses of interwoven neurofilaments (Liberski 1994). The neurons are generally well preserved in the gray substance and could be diffuse proliferation of microglia, gemistocystic and fibrilar gliosis that is also present in the white matter (Iwasaki 1990).

In all cases, the wall of the arteries and veins are thickened due to proliferation of the adventitia, but the lumen is normal and the endothelium does not show any abnormality. $50 \%$ of the cases have several arteries or veins surrounded by lymphocytic cuffs; these vessels are seen in the lateral posterior columns, and also in the gray substance. Curiously, the monocytic infiltration is usually more intense in those areas with better tissue preservation (Cartier 1997, Iwasaki 1990). The immunohistological studies of the spinal cord show Tlymphocytes CD4, specially $\mathrm{CD} 8$, and macro-phages. Also it has been observed apoptotic T lymphocytes, TNF-(and IL-1) these vessels. (Umehara 1993, Umehara 1994, Umehara 1994). It was also found perivascular T-cells infected with HTLV-I (Matsuoka 1998). There are vascular changes and lymphocytic cuffs in medulla, pons, midbrain and basal ganglia's. The tissue lesions are not limited to the spinal cord, almost in $50 \%$ of the cases the brain whitematter, especially in the subcortical areas, shows myelin and axon changes, that do not affect the U fibers (Kira 1991, Cartier 1997).

Clinical and pathological findings in the HAM/ TSP became very similar in Japanese and Chilean patients, but there are some differences in the associated pathology. Dacryosialadenitis HTLV-I (Sjögren Syndrome) is present in about $25 \%$ of Japanese HAM/TSP (Ijichi 1991). Is very frequent, in Chilean patients with a incidence of $40 \%$. In our view is part of the clinical picture of HAM/TSP (Cartier 1995, Cartier 1997).
It has been easily verified by Schirmer test and salivary gland biopsy. This dacryosialadenitis does not have the classical immune reaction of primary or secondary Sjbgren S., suggesting a viral origin.

The skin lesions are a frequent associated pathology, they consist of skin erythema, papules and/or dry skin desquamation; their histological findings are similar to infiltrations seen in the mycosis fungoide, sometimes with Pautrie abscess. These skin lesions rise to $25 \%$ in Chilean cases (Cartier 1995, Cartier 1996), in the Japanese patients is not common. These skin lesions are transient, persisting only some days, or weeks, in a few number of cases these changes are more permanent.

Arthropathy is an associated pathology present in $17 \%$ of HAM/TSP in Japan, is an arthrities that present HTLV-I infects synovial cells, also a rheumatoid factor could be positive (Sato 1991, Sakei 1993, Kitajima 1991). In Chile is rarely seen (Cartier 1992). Broncoalvolitis was found in $50 \%$ of the studied cases of HAM/TSP in Japan (Nakagawa 1995), but in Chilean patients is less than $10 \%$ (Cartier 1992). On chest radiograph there are abnormal findings caused by infiltration of $\mathrm{T}$ lymphocyte (Sugimoto 1987). Associated Iymphoma is present in more than $10 \%$ of HAM/ TSP in Chile, is an exceptional finding in Japan (Cabrera 1994). Ubeitis or retinal vasculitis is frequent in Japan (Mochizuki) but it has never been reported in Chile.

The number of other neurological compromises, like subcortical dementia is not clear yet others neurological compromise like subcortical dementiau. (35\% in Chilean patient cases) (Cartier and Gómez 1997), pseudobulbar compromise or Parkinson's syndrome, complications that are evidently present in Japan as in Chile. Polyneuropathies or polymyositis, those both pathologies are not associated with HAM/TSP in Chile nor in Japan. There are neuropathies and polymyositis associated with HTLV-I, but not with HAM/TSP in Chile (Cartier and Prina 1996).

The summing up is that HAM/TSP looks similar both in Japan and Chile with exception of the incidence of associated pathology, and epidemiological expression, where some genetic or environmentals factors could play a rol. 


\section{REFERENCES}

ARIMURA, K., ROSALES, R., OSAME, M. and 1GATE. A., 1987 Clinical electrophysiological studies of HTLV-I associated myelopathy. Arch. Neurol. 44: 609-612.

ARIMURA, Y., ARIMURA, K., OSAME, M., et al. Neuro1987 ophtholmological abnormalities in HTLV-I associated myelopathy. Neurophthalmol 7: 243-248.

CABRERA, M.E., LABRA, S., CATORSKY, D., et al. HTLV$1994 \quad$ I positive adult T-ceIl leukemia/ lymphoma (ATLL) in Chile. Leukemia 8:1763, 1767.

CARTIER, L., MORA, C., ARAYA, F., et al. HTLV-I positive 1989 spastic paraparesis in a temperate zone. Lancet 1: 556-557.

CARTIER, L., ARAYA, F., CASTILLO, J.L. et al. Progressive 1992 Spastic paraparesis associated with human T-cell leukemia virus type I (HTLV-I). Intern. Med. 31: 1257-1261.

CARTIER, L., ARAYA, F.,CASTILLO, J.L. HTLV-I clinical 1992 pathological spectrum. Rev. Med. Chile 120: 927-933.

CARTIER, L., TAJIMA, K., ARAYA, F., CASTILLO, J.L. et 1993 al. Preliminary report on the prevalence of serum antibodies against HTLV-I in Chilean aboriginal populations. Rev. Méd. Chile 121; 242-46.

CARTIER, L., CASTILLO, J.L., CABRERA, M.E., et al. 1995 HTLV-I positive progressive spastic paraparesis (TSP) associated with Iymphoid disorder in three Chilean patients. Leukemia Lymphoma 17: 459-464.

CARTIER, L., CASTILLO, J.L., CEA, J.G. and VILLAGRA. 1995 R., Chronic dacrosialoadenitis in HTLV-I associated myelopathy. $\mathbf{J}$. Neurol Neurosurg Psychiatry 58: 244-246

CARTIER, L., VERGARA, C., RAMIREZ, E., CASIVAR, T. 1995 and VAQUEZ, A. Seroprevalence of HTLV-I in close relatives of patients with spastic paraparesis. Rev. Méd. Chile 123: $7-11$.

CARTIER, L. and CARTIER, E. HTLV-I-II in Chile, in HTLV, 1996 Truths and questions. Edt. Zaninovic V., Cali Colombia Septiembre, pp. 150158.

CARTIER, L. and PRINA, L., Polymyositis associated to 1996 HTLV-I infection. Rev. Med. Chile 124: 461-464.

CARTIER, L., CEA, J.G., VERGARA, C., et al. Clinical and $1997 \quad$ Neuropathological study of six patients with spastic parparesis associated with HTLV-I An axomyelinic degeneration of the Central Nervous System. J. Neuropath. exp. Neurol. 56: 403-413.

CARTIER, L., GARCIA, L., LOPEZ, E., et al. HTLV-I 1997 associated myelopathy and chronic dacryosialoadenitis: A common association. J. Neurol Sci. S 150: S72.

CARTIER, L., GORMAZ, A. Human T lymphotropic virus I 1997 (HTLV-I) associated with cognitive impairment in TSP/HAM. J. Neurol Sci S 150: S294 (abstrac).
CARTIER, L., GORMAZ, A., KLEINSTEUBER, K., RAMI1997 REZ, E., GALENO, H. New form of subcortical dementia; encephalopathy due to infection with human lymphotropic T virus (HTLV-I). Rev. Méd. Chile 125(2): 209-213.

CASTILLO, J.L., CARTIER, L., ARAYA, F., VERDUGO, R., 1991 et al. Evoked potentials abnormalities in progressive spastic paraparesis associated to HTLV-I. Acta Neurol Scand 83: 151154

CASTILLO, J.L., CEA, JG., VERDUGO, R.J. and CARTIER, 1995 L. Sensory dysfunction in progresive HTLV-I positive and negative spastic paraparesis. Electroenceph clin Neurophysiol S97: S 140.

FERRAZ, A.C., GABBAI, A.A., ABDALA, N. GOMEZ, NO1997 GEIRA R., Ressonáncia magnética na mielopatia associada ao HTLV-I. Leucoencefalopatia e atrofia medular. Arq. Neuro Psiatría 5: 728-736.

GESSAIN, A., BARIN, F., VERNANT, J.C., et al. Antibodies 1985 toHumanT-lymphotropicVirusinpatients with tropical spastic paraparesis. Lancet ii: 407-410.

GIRAUDON, P., BUARTS, BERNARD, A., et al. Extracellular 1996 matrix-remodelingmetalloproteinasesand infection of the central nervous system with retrovirus human $\mathrm{T}$ lymphotropic virus type I (HTLV-I). Prog. Neurobiol. 49: $169-184$

IJICHI, 1., NARUYAMA, 1., SUEHARA, M. OSAME, M. 1991 Tlymphocyte infiltration in the minor salivary glans of patients with HTLV-I associated myelopathy. JPN J. Rheumatol 3: 131-136.

ZUMO, S., HIGUCHI, I. IJICHI, T. et al. Neuropathology 1989 study in tow autopsy case of HAM/TSP in Japan. Proceeding of the first Work-Shop on Neuropathology of retrovirus infections. Edit Iwasaki Y., Tokyo, pp. 717.

IWASAKIY. Pathology of chronic myelopathy 1990 associated with HTLV-I infection (HAM/TSP). J. Neurol. Sci 96: 103-123.

KAKIGI, R., SHIBESAKI. H., KURODA, Y., et al. 1998 Multimodality evoked potentiales in HTLV-I associated myelopathy. J.

Neurol. Neurosurg Psychiatry 51: 10941096.

KIRA, J. FUJIHARA, ITOYAMA, Y., GOTO, I., HASUO, 1991 K. Leukoencephalopathy in HTLV-I associated myelopathy/tropical spastic paraparesis MRI analysis and a tow year follow up study after corticoteroid therapy. J. Neurol Sci 106: 41-49.

KITAJIMA, I., YAMAMOTO, K. SATO, K. NAKAJIMA, Y., 1991 et al. Detection of human $\mathrm{T}$ cell Iymphotropic virus type I proviral DNA and its gene expession in synoviral cells in chronic inflammatory arthropathy. J. Clin Invest 88: 1315-1318. 
KOBAYASHI, I., OTA K., YAMAM OTO, K., et al. An autopsy 1989 case of HTLV-I associated myelopathy. Neurol Med. 30: 409-412.

LIBERSKI, P.P., ROGERS-JONSON. P., YAMAGIHARA, R., 1994 et al. Ultrastuctural pathology of human T-cell Iymphotropic virus type I. Encepha-lomyelopathy in a white patient with adult T-cell leukemia/ lymphoma.

Ultrastuctural Pathology 18: 511-

518. MATSUOKA. E., TAKENOUCHI, N., HASHIMOTO, K., et 1998 al. Perivascular $\mathrm{T}$ cell are infected with HTLV-I in the spinal cord lesions with HTLV-I associated myelopathy/ tropical spastic paraparesis: double staining of immunohisto chemistry and polymerase chain reaction in situ by lybridization. Acta Neuropathol. 96: 340-346.

MIURA, T., YAMASHITA, M., ZANINOVIC, V., CARTIER, 1997 L., et al. Molecular phylogenic of Human T-cell leukemia virus type I and II of Amerindians in Colombia and Chile. J. Mol Evol 44 (supl); S76-S82.

MOCHIZUKI, WATANABE, T., YAMAGUSHI, K., et al. 1992 Uveitis associated with human T-cell lymphotropic virus. Ann. J. Ophtalmology 114:123-129.

NAKAGAWA, M., IZUINO, S.H., IJICHI, S.H., KUHOTA,H., 1995 et al. HTLV-1 associated myelopathy: analysis of 213 patients based an clinical features and laboratory findings. J. Neurovirology 1: 50-61.

OSAME, M., USUKU, K., IZUMO, S., et al. HTLV-I associated 1986 myelopathy, a new clinical entity. Lancet is $397-398$.

OSAME, M., MATSUMOTO, M., USUKU, K., et al. Chronic 1987 progressive myelopathy associated with elevated antibodies to human lympho-tropic virus type-I and adult T cell leukemia-like cells. Ann Neurol 21:11722.

OSAME, M., JANSSEN, R., KUBOTA, H., et al. Nationwide 1990 survey of HTLV-I associated myelopa thy in Japan: Association with blood transfusion. Ann Neurol 28: 50-56.

RAMIREZ, E., CARTIER, L., RIOS, M. FERNANDEZ, J. 1998 Defective Human T-cell lymphotropic virus type I (HTLV-I) Provirus in 10 Chilean seronegative patients with tropical spastic of HTLV-I associated a Myelopathy. J. Clinical Microbiology 36: 1811-1813.
SAKEI, M., EGUCHI, K., TERADA, K., et al. Infection of 1993 human synoviral cell by human T-cell lymphotropic virus type 1 . Proliferation and granulocyte/macrophage colonystimulation factor production by synoviral cells. I. Clin Invest. 36: 1612-1620.

SATO, K., MARUYAMA, I., MARUYAMA, Y., et al. Arthritis 1991 in-patients infected with human $\mathrm{T}$ lynphotropic virus lype I Clinical and inmuno pathologic feature. Arthritis Rheum 34: 714-721.

SONODA, S. YASHIKI, S., FUJIYOSHI, T., et al. 1992 Inmunogenetic factors involved in he pathogenesis of adult T-cell leukemia and HTLV-I associated myelopathy. Gann Neurograph on Cancer Research 39: 81-93.

SUGIMOTO, M., NAKASHIMA, H., WATANABE, S., et al. 1987 T-lymphocyte alveolitis in HTLV-I associated myelopathy. Lancet ii: 1220.

TAKEZAKI,T.,TAJIMA, K. Epidemiology of ATLL and HAM/ 1996 TSP in Asia, in Truths and questions. Ed. Zaninovic U. Cali. Colombia, pp 6677.

TOMITA, 1., MOTOMURA, M., NAGASATO, K., et al. Con1989 trol motor conduction time (CCT) inpatients with human T-Iymphotropic virus type 1 associated myelopathy (HAM) in HTLV-I and Nervous system. Edt. Roman GC., Vernant J.C., Osame M., N.Y. Alan R. Liss, pp 239244.

UMEHARA, F., IZUMO, S., NAKAGAWA. M., et al. 1993 lmmunocytochemical analysis of the cellular infiltrate in the spinal cord lessions in HTLV-I associated myelophaty. J. Neuropath exp. Neurol. 52: 424-430.

UMEHARA, F., IZUMO, S.H., RONQUILLO, A.T., et al. $1994 \quad$ Cytokine expression in spinalcord lesions in HTLV-I associated myelopath. J. Neuropath exp. Neurol 53: 72-77.

UMEHARA,F..NAKAMURA,A.,IZUMO,S.,KUBOTA,K., 1994 et al. Apoptosis of lymphocytes in the spinal cord lesions in HTLV-1 associated myelopathy. A possible mechanisme to control viral. Infection in the central nervous system. J. Neuropath exp. Neurol 53: 617-629.

UMEHARA, F., OKADA, Y, FUJIMOTO, N., et al. Expression 1998 of matrix metalloproteinases and tissue inhibitors of metalloproteinases in HTLV-I associated myelopathy. J. Neuropath exp. Neurol 54: 839-849. 